\title{
PENERAPAN METODE DAKWAH ORANG TUA DALAM MENANAMKAN NILAI-NILAI AGAMA KEPADA ANAK DI DESA AEK GOTI KEC. SILANGKITANG KAB. LABUHANBATU SELATAN
}

\author{
Elismayanti Rambe \\ Program Studi Komunikasi dan Penyiaran Islam STAI As-Sunnah Deli Serdang \\ J1. Medan-Tg. Morawa, km. 13, Gg. Darmo, Bangun Sari, Tg. Morawa, Deli Serdang, SUMUT \\ elis.mayanti8@gmail.com
}

\begin{abstract}
Abstrak: Orang tua memiliki metode yang hampir sama dalam memberikan pemahaman nilai-nilai agama kepada anak yang secara umum sesuai dengan surat An-Nahal 125, yaitu dengan hikmah dan nasihat yang baik. Selain itu orang tua juga memberikan contoh atau suri tauladan yang baik, tidak hanya mengajarkan agama kepada anak namun ikut serta mengajak anak-anak bersamasama untuk beribadah. Dengan membiasakan anak beribadah sehingga bisa menjadi rutinitas anak, dan anak merasa bahwa ibadah kepada Allah sudah merupakan kewajiban dan dilaksanakan dengan senang hati tanpa merasa terpaksa. Untuk mendapatkan pemaaman agama anak secara baik diperlukan juga institusi keagamaan atau pendidikan yang dapat menunjangnya. Namun tetap keluarga yang memegang kendali atas perkembangannya. Penanaman nilai agama didalam keluarga sangat Menentukan kualitas agama anak melalui metodemetode yang sudah dilakukan oleh orang tua di Desa Aek Goti dalam menanamkan nilai-nilai agama kepada anak secara umum sudah efektif.
\end{abstract}

Kata Kunci : Metode Dakwah, Orang Tua, Nilai-nilai Agama, Anak.

\section{Pendahuluan}

Keluarga merupakan ladang awal terbaik untuk menyemaikan nilai-nilai agama kepada anggota keluarganya terutama anak. Demi orang tua pasti mendambakan anak yang beriman dan bertakwa, yang soleh dan solehah baik secara individu maupun secara sosial. Sebaliknya tidak ada orang tua yang menginginkan anaknya menjadi orang yang buruk perangai dan karakternya.

Meskipun tidak ada satu orangtua yang menginginkan anaknya jahat dan berperangai buruk namun realitas dilapangan kita temui kenakalan-kenakalan anak dan kejahatan lain seperti perkelahian, bicara yang tidak baik, bahkan melawan orang tua, mencuri, dan lain-lain. Oleh karenanya untuk menghindari hal-hal yang tidak di inginkan peranan orang tua dalam memberikan pemahaman teradap nilai-nilai agama kepada anak sejak usia dini sangat penting. 
Sebagai umat beragama, orang tua dan pendidik berkewajiban untuk menanamkan dasar-dasar aqidah yang benar kepada anak sejak usia dini, sebab ajaran agama merupakan sumber rujukan nilai yang sangat fundamental bagi kepentingan hidup manusia beragama. Apabila nilai-nilai aqidah itu sudah dibangun pada diri anak sejak usia dini, maka hal tersebut akan menjadi suatu landasan esensial bagi perkembangan kehidupan keagamaan anak pada tahaptahap berikutnya. Seperti yang dijelaskan oleh ulama kaum muslimin dalam kitab Ihya Ulumuddin yaitu:

Sesungguhnya anak kecil itu amanat kedua orang tuanya. Hatinya masih bersih dan kosong, ia menerima setiap goresan dan cenderung kemana ia diarahkan. Jika dibiasakan dan diajari kebaikan ia akan tumbuh pada kebaikan dan berbahagia didunia dan diakhirat. Jika sudah memasuki usia akil baligh ia sudah banyak terpengaruh olehnya,karena mengukir pada hatinya sama gampangnya seperti mengukir seonggok batu. Tetapi kalau ia tumbuh kebalikannya seperti ia masih suka bermain, saka berbuat jahat, makan makanan yang tidak halal, memakai pakaian yang haram, mengenakan perhiasan yang syubhat, sombong dan lain sebagainya itu berarti menandakan hatinya sukar menerima kebenaran. Ibarat tembok yang sukar ditempeli pasir yang kering

Bahkan dalam Al-Qur'an serta Sunnah banyak sekali ditegaskan tentang pentingnya mendidik anak bagi para orang tua. Anak yang terdidik dengan baik oleh orang tuanya akan tumbuh menjadi anak yang pandai menjaga dirinya dari pengaruh buruk lingkungan, karena ia telah dibekali oleh ilmu tentang hidup dan kehidupan yang di dalamnya terdapat ilmu yang paling bermanfaat yaitu ilmu agama.

Sementara itu Clark berpendapat, religiositas berkembang sejak usia dini melalui proses perpaduan antara potensi bawaan keagamaan dengan pengaruh yang datang dari luar diri manusia. Dalam proses perkembangan tersebut akan terbentuk macam, sifat, serta kualitas religiositas yang akan terekspresikan pada perilaku kehidupan sehari-hari. Proses perkembangan religiusitas melewati tiga fase utama, yakni fase anak, remaja dan dewasa. Masing-masing fase perkembangan memiliki kekhasan dalam sifat serta perannya terhadap keseluruhan perkembangan religiusitas. ${ }^{1}$

\footnotetext{
${ }^{1}$ Zein Muhammad, Methodologi Pengajaran Agama, ( Yogyakarta : AK Group dan Indra Buana, 1995), h. 11
} 
Desa Aek goti merupakan desa yang mayoritas penduduknya beragama islam. Berdasarkan observasi awal yang dilakukan peneliti banyak orang tua yang memiliki pemahaman agama yang baik atau bisa dianggap sebagai tokoh agama dimasyarakat namun anaknya tidak mencerminkan nilai-nilai agama yang baik, bahkan ada yang masih mendudukan SD namun sudah mulai merokok walaupun itu dilakukan secara sembunyi-sembunyi, ada yang masih belum bisa membaca alquran, dan belum memiliki akhlak yang baik, sedangkan ada yang orang tuanya yang sedikit pengetahuan agama namun anaknya telah mencerminkan nilai-nilai agama yang baik, sholat ke mesjid setiap hari, membaca al Quran setelah selesai shalat maghrib, dan mempunyai sopan santun yang baik.

Berdasarkan fenomena yang telah peneliti uraikan diatas maka peneliti sangat tertarik untuk melakukan penelitian secara mendalam dengan judul "Penerapan Metode Dakwah Orang Tua Dalam Menanamkan Nilai-Nilai Agama Kepada Anak Di Desa Aek Goti Kec. Silangkitang Kab. Labuhanbatu Selatan".

\section{Pembahasan}

\section{Dakwah Sebagai Perintah Agama}

Kata dakwah berasal dari bahasa yaitu Ad-dakwah sebagai bentuk kata masdar dari kata da'a -yad'u. Menurut Dr Taufiq Al-Wa'i defenisi dakwah islam yaitu " mengumpulkan manusia dalam kebaikan, menunjukan mereka jalan yang benar dengan cara merealisasikan manhaj Allah dibumi dalam ucapan dan amalan, menyeru kepada yang ma'ruf mencegah kepada yang munkar, membimbing mereka kepada shiratal mustaqim dan bersabar menghadapi ujian yang menghadapi ujian diperjalanan. Sedangkan menurut Muhammad Natsir "Dakwah adalah suatu usaha menyerukan dan menyampaikan kepada perorangan manusia dan seluruh umat, konsepsi islam tentang pandangan dan tujuan hidup manusia didunia ini yang meliputi amar ma'ruf nahi mungkar dengan membimbing pengalamannya dalam kehidupan berumah tangga (usrah)". ${ }^{2}$

\footnotetext{
${ }^{2}$ Asmuni Syukir, Dasar-dasar strategi dakwah islam ( Surabaya : Al Ikhlas, 1983), h. 34
} 
Dakwah islam adalah merupakan kewajiban bagi setiap orang islam baik secara perorangan maupun kolektif. Dasar hukum dakwah dari Alquran dapat dilihat dari Q.S Ali Imron ayat 104 :

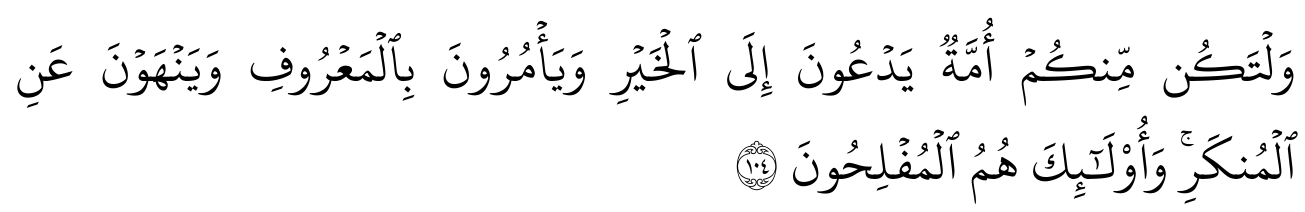

Dan hendaklah ada di antara kamu segolongan umat yang menyeru kepada kebajikan, menyuruh kepada yang ma'ruf dan mencegah dari yang munkar; merekalah orang-orang yang beruntung

Dari ayat diatas dapat dijelaskan bahwa menyarankan kebaikan (berdakwah) merupakan perintah Allah SWT untuk semua manusia sehingga tugas dakwah adalah merupakan tugas setiap individu umat islam. Islam adalah agama dakwah yaitu agama yang menugaskan umatnya untuk menyeru dan mengajak manusia untuk memeluk agama islam. ${ }^{3}$ Agar dakwah islam dapat berjalan secara maksimal maka dibutuhkan dukungan dari komponen atau unsurunsur dakwah yaitu sebagai berikut: ${ }^{4}$

a) Subjek dakwah adalah pelaku kegiatan dakwah atau dengan kata lain orang yang melakukan dakwah yang merubah situasi sesuai dengan ketentuan Allah. Usaha dakwah ini dilakukan secara lembaga., organisasi, atau yayasan dan sebagainya dan orang menyebutnya muballigh atau da'i.

b) Objek dakwah adalah penerima dakwah yang menjadi sasaran yaitu manusia, baik dirinya sendiri maupun orang lain.

c) Materi dakwah adalah bahan atau sumber yang dapat digunakan untuk berdakwah atau mencapai tujuan.

d) Metode berasal dari kata "meta" yang berarti melalui dan "hudos" yang berarti jalan. Jadi metode berarti jalan yang dilalui. Metode adalah cara yang teratur yang telah difikirkan baik dan terncana untuk mencapai suatu maksud. Jadi pengertian metode dakwah adalah cara yang teratur dan sistematis serta terkonsep dengan baik untuk mencapai perubahan kepada kondisi yang lebih baik sesuia dengan ajaran islam. ${ }^{5}$

\footnotetext{
${ }^{3}$ Abdul Rasyid Shaleh, Manajemen Dakwah, ( Jakarta : Bulan Bintang, 1997), h. 29

${ }^{4}$ Rafi'uddin dkk, Prinsip dan Strategi Dakwah (Bandung : pustaka setia, 1997), h. 24

${ }^{5}$ Wahidin saputra, Pengantar ilmu dakwah (Jakarta : kencana, 2011), h. 4-5
} 
e) Media dakwah adalah segala sesuatu yang dapat digunakan sebagai alat untuk mencapai tujuan dakwah yang telah ditentukan'. Alat atau media ini dapat berupa materi maupun immaterial, termasuk didalamnya adalah organisasi, dana, tempat dan juga bahasa.

\section{Pembentukan Karakter Anak Dalam Keluarga}

Karakter adalah sebuah kata yang tidak ada artinya jika tidak dihubungkan dengan manusia. Gordon mendefenisikan karakter manusia sebagai kumpulan atau kristalisasi dari kebiasaan-kebiasaan seorang individu. Sedangkan Chaplin mendefenisikan sebagai kualitas kepribadian yang berulang secara tetap dalam seorang individu. Dari sudut proses pembentukannya ada ahli yang mengatakan bahwa karakter manusia itu adalah turunan (hereditas), sebagian lain lagi mengatakan lingkungan yang membentuk karakter kepribadian seseorang. Kita tidak mempersalahkan atau membenarkan salah satu pandangan diatas. Yang pasti kedua faktor diatas sangat berperan didalam pembentukan karakter kepribadian seorang manusia. tapi yang paling penting untuk diperhatikan adalah bahwa kebiasaan manusia yang setiap hari itu lah yang akan membentuk karakter seorang manusia.

Beberapa aspek kepribadian manusia yang perlu dibiasakan sejak dini pada anak sehingga dapat membentuk satu kepribadian yang tangguh dan mandiri diwaktu yang akan datang. Beberapa aspek tersebut adalah sebagai berikut :

a) Responsibility ( tanggung jawab), aspek psikologis dari tanggung jawab ini adalah keberanian menerima tugas, komitmen menjalankan, ketahanan mental selama menjalankan, dan keterbukaan untuk menerima konsekuensi positif dan negatif. Maka seorang yang disebut punya karakter tanggung jawab berarti orang itu memiliki kesediaan untuk menerima, memiliki komitmen untuk menjalankan tugas tersebut sampai tuntas dan mengevaluasi serta menerima hasilnya baik positif maupun negatif.

b) Self-respect ( penghargaan terhadap diri sendiri). Penghargaan terhadap diri sendiri berarti berfikir positif dan menerima diri sendiri sebagaimana adanya. Dengan berfikir positif terhadap diri orang dapat menemukan potensi dan bakat yang terpendam didalamnya. Lalu dengan menerima 
hal-hal positif dan negatif yang ia miliki maka ia merasa aman dengan dirinya sendiri, dan akhirnya ia dapat tampil dengan penuh percaya diri. Penghargaan terhadap diri sendiri perlu dibangun sejak usia dini sehingga menjadi bekal ia dapat mengemban amanah untuk mensyiarkan ajaran islam

c) Doing the right thing : melakukan hal baik terutama dalam menanamkan nilai-nilai agama kepada anak perlu dibiasakan sejak dini. Kebiasaan ini dibentuk dengan latihan seperti latihan shalat lima waktu, membaca alquran. latihan ini dilakukan berulang kali tentu dengan tauladan yang diberikan oleh orang tua sehingga menjadi kebiasaan dalam kehidupannya sehari-hari.

d) Respecting other : sikap menghargai orang lain, ini perlu dikembangkan agar anak dapat memberikan sisi penghargaan terhadap temannya yang lain. Ia perlu juga menahan diri, memberi kesempatan kepada teman lain, menerima pendapat dan keinginan teman lain serta berani untuk menerima kekalahan, sikap ini mendukung anak untuk bisa melatih kesabaran, menerima orang lain, mendengarkan orang lain, dan mengakui kelebihan orang lain

e) Preventing conflicts dan violenve : sikap ini perlu ditumbuhkan kepada anak sejak dini agar dapat membantengi diri dari pertengakaran antar sesama anak yang sering terjadi seperti tawuran.

Keluarga merupakan satu-satunya lembaga sosial yang diberikan tanggung jawab untuk mengubah suatu organisme hidup menjadi manusia. Kedudukan utama keluarga berfungsi sebagai pengantar pada masyarakat yang lebih luas. Pendidikan dalam keluarga berlangsung secara tanpa disadari. Pengalaman yang didapat anak secara langsung lewat penglihatan, pendengaran, perlakuan, pembiasaan dan pelatihan. Anak menyerap, meniru dari orang-orang disekitarnya terutama orang tua.

\section{Hasil Penelitian}




\section{Penerapan Metode Dakwah Orang Tua Dalam Menanamkan Nilai-Nilai Agama Kepada Anak Di Desa Aek Goti Kec. Silangkitang Kab. Labuhanbatu Selatan.}

Untuk mengetahui bagaimana penerapan metode dakwah yang dilakukan oleh orang tua dalam menanamkan nilai-nilai agama kepada anak disini penulis melakukan wawancara mendalam kepada beberapa orang tua dari berbagai latar belakang yang berbeda. Dari hasil wawancara itu kemudian dianalisis dan ditarik kesimpulan bahwa dalam penerapan metode dakwah untuk menanamkan nilainilai agama kepada anak orang tua menggunakan dua metode dakwah yaitu dakwah bil lisan atau dakwah dengan perkataan dan dakwah bil halq ataupun dakwah dengan perbuatan.

Berdasarkan hasil wawancara dengan para orang tua dakwah bil lisan selalu diterapkan kepada anak. Orang tua selalu menanamkan nilai-nilai ajaran islam kepada anak sejak usia dini. Terutama menyampaikan tentang kewajibankewajiban yang harus dilaksanakan seperti shalat. Beberapa orang tua menyiapkan waktu khusus untuk bissa menyampaikan dakwah kepada anaknya, misalkan sehabis shalat maghrib berjama'ah seluruh anggota keluarga akan berkumpul dan ayah yang merupakan kepala keluarga akan menyampaikan kepada anak-anaknya tentang nilai-nilai ajaran islam, meskipun biasanya waktu yang digunakan itu sekitar 15 menit tetapi itu dilakukan secara intens atau terus menerus sehingga sudah menjadi rutinitas dalam sebuah keluarga. Sedangkan keluarga yang tidak menyiapkan waktu khusus untuk menyampaikan ceramah agama kepada anak biasanya akan menyampaikannya di sela-sela percakapan sehari-hari ataupun ketika anak bertanya makan disitu perang orang tua ayah dan ibunya akan menyampaikan pengajaran agama kepada anaknya.

Selain dakwah bil lisan orang tua juga menggunakan metode dakwah bil Halq yaitu dakwah dengan perbuatan. Orang tua tidak hanya sekedar menyampaikan nilai-nilai agama kepada anak, menyampaikan mana yang benar dan mana yang salah, melainkan mengajak anak untuk sama-sama menjalankan perintah agama. Contohnya orang tua tidak hanya menyampaikan bahwa sholat itu adalah kewajiban umat islam yang merupakan tiang agama tetapi orang tua juga mengajak anak-anak untuk sama-sama mengerjakan sholat, begitu juga dengan 
ibadah-ibadah yang lain, puasa, bersedekah, sopan santun, membaca alquran dan yang lain. Dalam hal ini orang tua menjadi suri tauladan atau menjadi contoh yang baik kepada anak sehingga anak dengan mudah mengikuti apa yang dilakukan oleh orang tuanya.

\section{Efektifitas Penerapan Metode Dakwah Orang Tua Dalam Menanamkan Nilai-Nilai Agama Kepada Anak Di Desa Aek Goti Kec. Silangkitang Kab. Labuhanbatu Selatan.}

Efektifitas pada dasarnya mengacu pada sebuah keberhasilan atau pencapaian tujuan. Efektifitas merupakan salah satu dimensi dari produktifitas 9 hasil yaitu mengarah pada pencapaian unjuk kinerja yang maksimal, yaitu pencapaian target yang berkaitan dengan kualitas, kuantitas, dan waktu. Efektifitas adalah ukuran yang menyatakan seberapa jauh target (kuantitas, kualitas, dan waktu) telah dicapai. dimana makin besar target yang telah dicapai maka makin tinggi effektifitasnya. ${ }^{6}$

Kegiatan dakwah akan dikatakan efektif apabila dimanifestasikan dengan cara yang tepat. Metode dakwah tidak boleh kaku dan statis baik dalam penerapan strateginya maupun tekniknya.akan tetapi harus mampu mengikuti dinamika yang ada. Apabila metode dalam aplikasinya kaku dan statis, maka ajaran-ajaran yang didakwahkan tidak akan mendapat respon yang baik terlebih orang yang ingin didakwahi tersebut adalah anak-anak, karena itu metode dakwah yang digunakan orang tua adalah bagian dari sistem yang sangat berpengaruh dalam menentukan keberasilan dakwah. $^{7}$

Selama berada di lokasi penelitian selain melakukan Wawancara penulis juga melakukan observasi terhadap kegiatan anak-anak di Desa Aek goti kec. Silangkitang bahwa anak-anak selau mengikuti shalat maghrib berjama'ah di masjid dan setelah itu mereka juga mengaji mulai dari iqra' sampao membaca alquran. Ada beberapa guru mengaji yang ada di desa tersebut yang sudah sejak lama mengajari anak-anak menbaca alqur'an. Ketika pada bulan ramadhan anakanak juga bersemangat untuk berpyasa yang dilanjutkan pada malamnya untuk

\footnotetext{
${ }^{6}$ Widodo dkk, Kamus ilmiah popular dilengkapi EYD dan pembentukan istilah, (Yogyakarta : Absolut 2002), h. 114

${ }^{7}$ Helmi Masdar, Dakwah dan Pembangunan, ( Jakarta : Wijaya, 1976), h. 68
} 
ikut shalat taraweh dan tadarus al Quran. Selain berdasarkan hasil observasi penulis juga melakukan wawancara apakah metode yang diterapkan selama ini sudah effektif dan seluruh responden menjawab apabilan kedua metode dakwah tadi dilakukan dengan baik secara lisan dan perbuatan maka anak-anak akan dengan meudah menjalankan perintah agama. Adapun sebagian anak-anak yang masih tidak mengerti agama karena ketidak pedulian orang tua dan anak disuruh membantu orang tua ke ladang dan putus sekolah. Jadi bisa disumpulkan secara keseluruhan metode dakwah yang sudah diterapkan selama ini berjalan effektif. Karena anak-anak sudah mengerti nilai-nilai dasar agama, tidak hanya mengerti tteapi mereka juga ikut menjalankan perintah agama di suia yang masih kecil.

\section{Tantangan dan Hambatan Penerapan Metode Dakwah Orang Tua Dalam Menanamkan Nilai-Nilai Agama Kepada Anak Di Desa Aek Goti Kec. Silangkitang Kab. Labuhanbatu Selatan.}

Menanamkan nilai-nilai agama anak tentunya tidak selalu berjalan dengan sempurna, banyak halangan dan rintangan yang dihadapi oleh anak-anak, karena setelah mengarungi kehidupan dilingkungan keluarga anak-anak akan mendapatkan pengalaman baru dan suasana baru, yaitu dalam lingkungan masyarakat. Artinya anak-anak dituntut harus dapat berintegrasi dengan dunia luarnya tanpa harus mengikuti pergaulan dan perubahan yang ada dilingkungan masyarakatnya.

Selain itu juga dalam penanaman nilai-nilai agama tidak begitu saja berjalan dengan sempurna karena pada diri anak mempunyai fase-fase tersendiri mengenai perkembangan agama. Menurut penelitian Ernest Harms perkembangan agama anak-anak itu melalui beberapa fase (tingkatan) yaitu:

1. The Fairy Tale Stage (Tingkat Dongeng), tingkatan ini dimulai pada anak yang berusia 3-6 tahun, pada fase ini konsep mengenai tuhan lebih banyak dipengaruhi oleh fantasi dan emosi, hingga dalam menanggapi agama juga anak masih menggunakan konsep fantastis yang diliputi ole dongeng-dongen yang tidak masuk akal.

2. The Realistic Stage (Tingkat Kenyataan), tingkat ini dimulai pada saat anak memasuki Sekolah Dasar hingga ke usia (masa usia) adolesense. Pada masa 
ini ide ketuhanan anak sudah mencerminkan konsep-konsep yang berdasarkan kepada kenyataan (realitas). Pada masa ini anak-anak tertarik dan senang pada nilai-nilai keagamaan dan lembaga keagamaan yang mereka liat dikelola oleh orang dewasa dalam lingkungan mereka, segala bentuk tindak (amal) keagamaan mereka ikuti dan pelajari dengan penuh minat.

3. The Individual Stage ( Tingkat Individu), pada tingkat ini anak telah memiliki kepekaan emosi yang paling tinggi sejalan dengan perkembangan usia mereka. Konsep tersebut terbagi tiga yaitu:

a. Konsep ke-Tuhanan yang masih konvensional dan konservatif dengan dipengaruhi sebagian kecil fantasi yang dipengaruhi oleh luar

b. Konsep ke-Tuhanan yang lebih murni yang dinyatakan dalam pandangan yang bersifat personal

c. Konsep ke-Tuhanan yang bersifat Humanistik. Agama telah menjadi etos humanis pada diri mereka dalam menghayati ajaran agama. Perubahan ini setiap tingkatan dipengaruhi oleh faktor intern, yaitu perkembangan usia dan fakor ekstern berupa pengaruh luar yang dialaminya.

Menanamkan nilai-nilai agama memang tidak sesulit dari apa yang diperkirakan, ketika pendidikan agama yang diberikan pada fase sebelumnya (balita) dirasa tepat dan sesuai, akan tetapi sebaliknya jika pendidikan agama kurang diberikan dan bahkan tidak diberikan sama sekali, misalnya dalam hal melaksanakan shalat, walaupun hal itu sudah diwajibkan bagi orang tua untuk mengajarkan shalat kepada anak-anaknya seperti yang disebut dalam Alquran Surat Luqman ayat 17, yaitu :

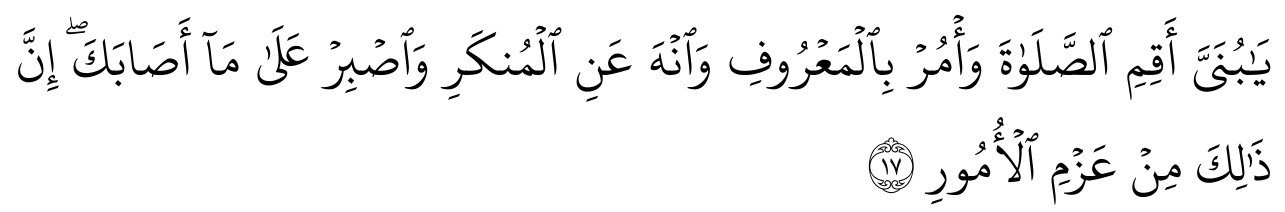

Hai anakku, dirikanlah shalat dan suruhlah (manusia) mengerjakan yang baik dan cegahlah (mereka) dari perbuatan yang mungkar dan bersabarlah terhadap apa yang menimpa kamu. Sesungguhnya yang demikian itu termasuk hal-hal yang diwajibkan (oleh Allah) 
Dari penjelasan diatas menunjukkan bahwasanya ketika seorang anak mengamalkan ajaran agamanya, maka ia akan mengerjakan shalat, bersabar, mengerjakan kegiatan atau aktifitas yang baik sehingga dapat mencegah dari perbuatan jelek. Dapat dikatakan juga bahwa seorang anak yang mengamalkan ajaran agamanya adalah anak yang menjalani rukun iman dan islam serta berbuat baik terhadap sesamanya. Karena syarat utama seseorang diterima amal kebajikannya di sisi Allah SWT adalah ia memiliki keimanan baik dan keislaman yang saleh. Tanpa iman dan islam seseorang tidak pernah diterima oleh Allah walau ia suka menolong, membantu, atau mungkin hartanya melimpah ruah sebab iman dan islam merupakan akar urat dari segala kebajikan.

Hambatan dari segi orang tua adalah kesibukan bekerja atau mencari nafkah, dan ada sebagian orang tua baik ayah maupun ibu yang sibuk bekerja sehingga tidak setiap hari bisa berdiskusi dengan anak-anak terkait ajaran agama, namun orang tua selalu berusaha menyempatkan waktu untuk tetap bisa dekat dan diskusi dengan anak-anak meskipun tidak setiap hari. Karena rata-rata orang tua adalah petani yang seharian bekerja dikebun. Selain itu orang tua juga menyekolahkan anak di MDA sehingga dari lembaga itu mereka memperoleh pemahaman nilai-nilai agama.

Hambatan dari anak biasanya mereka juga ada masa untuk malas-malasan mungkin karena lelah dengan aktifitas yang padat setiap hari, dari pagi masuk sekolah umum, kemudian jam 2 siang harus sekolah lagi disambung ba'da maghrib membaca alquran. Solusi yang diberikan orang tua biasanya dengan memberikan semangat atau motivasi kepada anak-anaknya dengan perkataan yang lembut dan penuh kasih sayang. Dan beberapa orang tua juga sering mengajak anak berlibur ataupun dengan menuruti keinginan dari sang anak agar mereka tetap semangat untuk belajar, khususnya belajar tentang islam. 


\section{Penutup}

Berdasarkan hasil penelitian dengan judul penerapan metode dakwah orang tua dalam menanamkan nilai-nilai agama kepada anak di desa Aek Goti kec. Silangkitang Kab. Labuhanbatu Selatan" bahwa orang tua memiliki metode yang hampir sama dalam memberikan pemahaman nilai-nilai agama kepada anak yang secara umum sesuai dengan surat An-Nahal 125, yaitu dengan hikmah dan nasihat yang baik.

Selain itu orang tua juga memberikan contoh atau suri tauladan yang baik, tidak hanya mengajarkan agama kepada anak namun ikut serta mengajak anakanak bersama-sama untuk beribadah. Dengan membiasakan anak beribadah sehingga bisa menjadi rutinitas anak, dan anak merasa bahwa ibadah kepada Allah sudah merupakan kewajiban dan dilaksanakan dengan senang hati tanpa merasa terpaksa.

Untuk mendapatkan pemaaman agama anak secara baik diperlukan juga institusi keagamaan atau pendidikan yang dapat menunjangnya. Namun tetap keluarga yang memegang kendali atas perkembangannya. Penanaman nilai agama didalam keluarga sangat Menentukan kualitas agama anak melalui metodemetode yang sudah dilakukan oleh orang tua di Desa Aek Goti dalam menanamkan nilai-nilai agama kepada anak secara umum sudah efektif. 


\section{Pustaka Acuan}

Anshari, Hafi. Pemahaman dan Pengalaman Dakwah, Surabaya : Al Ikhlas, 1993.

Arifin, M. Hubungan timbal balik pendidikan agama di lingkungan sekolah, dan keluarga, Jakarta : Bulan Bintang, 1986.

Arikunto.Suharismi, Prosedur Penelitian, Jakarta : Rineka Cipta,1997.

Asmuni Syukir, Dasar-Dasar Strategi Dakwah Islam, Surabaya:Penerbit Al Ikhlas, 1995

Bungin.Burhan, Metodologi Penelitian Kualitatif, Jakarta : PT Raja Grafindo Persada, 2001

Cholid Narbuko dan Abu Ahmadi, Metode Penelitian.Bumi Aksara,Jakart, 2003

Clark, W.H, The Psychology Of Religion. New York : The MacMillan Company, 1958

Daradjat.Zakiah, Ilmu jiwa agama, Jakarta : Bulan Bintang, 1970.

Dzikron Abdullah, Metodologi Dakwah, Semarang: Fakultas Dakwah IAIN Walisongo, 1989.

Hasanuddin, Hukum Dakwah, Jakarta : Pedoman ilmu jaya, 1996.

Helmy.Masdar, Dakwah dan Pembangunan Jakarta : Wijaya, 1976.

HM. Arifin, hubungan timbal balik pendidikan agama di lingkungan sekolah dan keluarga, Jakarta : Bulan Bintang,1996.

M. Munir, Metode Dakwah, Jakarta : kencana, 2009.

Miles B. Mathew, Qualitative Data Analysis ; asovrcebook of New Methods, Baverly Hills : Sage Peblication, 1992.

Nuh. Sayid Muhammad, Dakwah Fardhiyah, Surakarta: Era Intermedia 2000 .

R.C Bogdan dan S.K Biklen, Qualitative Research for Education An. Introduction To Theory and Methods, Boston Allyn and Bacon, Inc 1982.

Rakhmat.Jalaluddin, Metode Penelitian Komunikasi Dilengkapi Contoh Analisis Statistik, Bandung : Remaja Rosdakarya, 1995

Sutirman Eka Ardana, Jurnalistik Dakwah Yogyakarta : Pustaka Pelajar, 2003.

Shaleh. Abd Rosyad, Manajemen dakwah, Jakarta : Bulan Bintang ,1977.

Zein.Mohammad, Methodologi Pengajaran Agama, Yogyakarta : AK Group dan Indra Buana, 1995. 